\title{
Nucleoside triphosphate diphosphohydrolase1 (TcNTPDase-1) gene expression is increased due to heat shock and in infective forms of Trypanosoma cruzi
}

\author{
Natália Lins Silva-Gomes', Vitor Ennes-Vidal' ${ }^{1}$, Julliane Castro Ferreira Carolo ${ }^{1}$, Marcos Meuser Batista², \\ Maria Nazaré Soeiro ${ }^{2}$, Rubem Menna-Barreto ${ }^{2}$ and Otacilio Cruz Moreira ${ }^{*}$
}

\begin{abstract}
Background: Ecto-Nucleoside Triphosphate Diphosphohydrolases (Ecto-NTPDases) are enzymes that hydrolyze tri- and/or di-phosphate nucleotides. Evidences point to their participation in Trypanosoma cruzi virulence and infectivity. In this work, we evaluate TCNTPDase-1 gene expression in comparison with ecto-NTPDase activity, in order to study the role of TcNTPDase-1 in parasite virulence, infectivity and adaptation to heat shock.

Findings: Comparison between distinct T. cruzi isolates (Y, 3663 and 4167 strains, and Dm28c, LL014 and CL-14 clones) showed that TCNTPDase-1 expression was 7.2 \pm 1.5 times higher in the Dm28c than the CL-14 avirulent clone. A remarkable expression increase was also observed in the trypomastigote and amastigote forms ( $22.5 \pm 5.6$ and $16.3 \pm 3.8$ times higher than epimastigotes, respectively), indicating that TCNTPDase-1 is overexpressed in T. cruzi infective forms. Moreover, heat shock and long-term cultivation also induced a significant increment on TcNTPDase-1 expression.
\end{abstract}

Conclusions: Our results suggest that TCNTPDase-1 plays an important role on T. cruzi infectivity and adaptation to stress conditions, such as long-term cultivation and heat shock.

Keywords: T. cruzi, TcNTPDase-1, Gene expression, Infectivity, Virulence

\section{Findings}

\section{Background}

Chagas disease is a neglected illness caused by the protozoan parasite Trypanosoma cruzi, which affects 8 million people in endemic areas of Latin America [1,2]. The different disease spectrums and the course of chronic infection may be consequences of complex interactions between genetic variability of $T$. cruzi subpopulations (classified into TcI to TcVI) [3], host immunogenetics and eco-epidemiological characteristics [3-5]. Current chemotherapy is based on the drugs nifurtimox and benznidazole, which present a lack of effectiveness on the chronic phase of the disease [6]. In this scenario, the search for new drugs and targets to chemotherapy is pivotal.

\footnotetext{
* Correspondence: otacilio@ioc.fiocruz.br

'Laboratorio de Biologia Molecular e Doenças Endêmicas, Instituto Oswaldo Cruz/ FIOCRUZ, Av. Brasil, 4365. Pavilhão Leônidas Deane, sala 209.

Manguinhos, Rio de Janeiro, Brazil

Full list of author information is available at the end of the article
}

Ecto-nucleoside triphosphate diphosphohydrolases (EctoNTPDases, EC 3.6.1.5) are enzymes that hydrolyze tri- and/ or di-phosphate nucleotides $[7,8]$. Since extracellular ATP is an immune-modulatory molecule that stimulates the secretion of IFN- $\gamma$ and IL-2 [9], it is hypothesized that ectoATPase activity in parasites can be important to the evasion mechanism from the host immune defense, although the mechanism is not clearly elucidated [10]. In 2004, a 2,282 base pair mRNA encoding a full-length NTPDase was cloned, sequenced [11] and named T. cruzi NTPDase-1 (TcNTPDase-1; Genbank: AY540630.1), which presents a single copy gene in the genome. In this work, we have developed a quantitative Real-Time RT-PCR assay to quantify TcNTPDase-1 mRNA levels, using TcGAPDH and TcCalmoduline as housekeeping genes (Additional file 1: Figure S1), aiming to contribute to the knowledge about the role of this NTPDase to T. cruzi infectivity and virulence. In this sense, we evaluated the TcNTPDase-1 
expression in distinct developmental forms (epimastigotes and cell culture-derived amastigotes and trypomastigotes) and parasite isolates, such as the $\mathrm{Cl}-14$, which is described as an avirulent T. cruzi clone, since it is unable to promote infection and to induce immune response in a murine model $[12,13]$.

During its life cycle, $T$. cruzi undergoes profound adaptations triggered by a wide range of environmental conditions between the vertebrate or invertebrate hosts, such as variations in $\mathrm{pH}$ and temperature. The epimastigote and metacyclic trypomastigote forms interact with the triatomine insect vector at $28^{\circ} \mathrm{C}$ and the amastigote and trypomastigote forms interact with the mammalian host at $37^{\circ} \mathrm{C}$. This heat shock may induce a response from the parasite, promoting the modulation of ecto-ATPase activity [14]. Thus, considering the importance of the ecto-NTPDase activity on the parasite's purine salvage pathway [15] and heat shock adaptation, the expression of TcNTPDase-1 was also analyzed during $T$. cruzi epimastigote cultivation, at different temperatures, to investigate the expression regulation in response to long-term cultivation or induced by heat shock.

\section{Methods}

\section{Parasite cultivation}

The T. cruzi Y, 3663, 4167 strains, and Dm28c, LL014 and CL-14 clones were obtained from the Coleção de Protozoários da Fundação Oswaldo Cruz (COLPROT-FIOCRUZ). T. cruzi laboratory-adapted epimastigotes were cultivated in BHI medium, supplemented with $10 \%$ heat-inactivated fetal bovine serum, at $28^{\circ} \mathrm{C}$ for 5 days, to reach late-log growth phase.

\section{Production of culture derived trypomastigotes and amastigotes}

The isolation of trypomastigote and amastigote forms was carried out using Vero cells, as detailed elsewhere [16]. Briefly, cell cultures were infected with mice-derived bloodstream trypomastigotes, in a 10:1 parasite/host cell ratio. Infected cells were maintained at $37^{\circ} \mathrm{C}$ in a $5 \% \mathrm{CO}_{2}$ atmosphere. After 5-6 days, the supernatant was collected, centrifuged at $500 \times \mathrm{g}$ for $5 \mathrm{~min}$, and allowed to stand at $37^{\circ} \mathrm{C}$ for $30 \mathrm{~min}$ for the migration of trypomastigotes into the supernatant. The amastigotes remained in the pellet.

\section{Ecto-ATPase and ecto-ADPase activity measurements}

The extracellular hydrolysis of ATP or ADP by intact parasites was carried out through the measurement of inorganic phosphate $(\mathrm{Pi})$ released in the supernatant, as previously described by De Souza et al. [17]. Briefly, ecto-ATPase and ecto-ADPase activities were estimated by the incubation of intact cells $\left(0.5 \times 10^{8}\right.$ parasites) for $1 \mathrm{~h}$ at $28^{\circ} \mathrm{C}$, in a reaction medium containing $116 \mathrm{mM} \mathrm{NaCl}, 5.4 \mathrm{mM} \mathrm{KCl}, 5.5 \mathrm{mM}$ d-glucose, $5 \mathrm{mM} \mathrm{MgCl}$, and $50 \mathrm{mM}$ Hepes-Tris buffer, in the presence of $5 \mathrm{mM}$ ATP or ADP (Sigma-Aldrich), in a final volume of $0.5 \mathrm{~mL}$. The reaction was started by the addition of living parasites and terminated by the addition of $1 \mathrm{~mL}$ of ice cold $\mathrm{HCl} 0.2 \mathrm{M}$. The cell suspensions were pelleted and supernatant aliquots were used for inorganic phosphate (Pi) quantification [17].

\section{RNA isolation and CDNA synthesis}

Total RNA from T. cruzi ( $1 \times 10^{8}$ cells) was extracted using TRIzol Reagent (Invitrogen, USA) and treated with DNAse I (Sigma-Aldrich, USA), following manufacturer's instructions. RNA quantity and purity was estimated by spectrophotometry at $260 / 280 / 230 \mathrm{~nm}$. RNA integrity was verified through electrophoresis on a $1.5 \%$ $(w / v)$ agarose gel. All reverse transcriptase reactions were performed from $3 \mu \mathrm{g}$ of RNA using a Superscript III First-strand System (Invitrogen, USA), according to the manufacturer's instructions.

\section{-NTPDase-1 gene expression quantification by Real-Time RT-PCR}

Real-time quantitative PCR assays were performed in ABI Prism 7500 fast sequence detection system using Power SYBR Green PCR mastermix (Applied Biosystems, USA). The following primers and concentrations were used: TcNTPDase-I Fw (600 nmol/L), 5'-GCGGAACCGCAA CACCCTCA-3'; TcNTPDase-I Rv (600 nmol/L), 5'CGGTCGAGCTGAAGCGCCAA-3'; TcCalmoduline Fw (600 nmol/L), 5'-CCCGACGGAGGCGGAGCTGC-3'; TcCalmoduline Rv (600 nmol/L), 5'-GTCCACGTCGGCC TCGCGGA-3'; TcGAPDH Fw (300 nmol/L), 5'-GTGCGG CTGCTGTCAACAT-3'; and TcGAPDH Rv (300 nmol/L), 5'AAAGACATGCCCGTCAGCTT- 3'. The conditions for the RT-qPCR were as follows: $95^{\circ} \mathrm{C}$ for 10 minutes, followed by 40 cycles at $95^{\circ} \mathrm{C}$ for 15 seconds and $62^{\circ} \mathrm{C}$ for 1 minute. To monitor the primers specificity, melting curves were performed after each experiment, resulting in a single peak. Reactions were performed in duplicates using $2 \mu \mathrm{L}$ of cDNA template, in a total volume of $20 \mu \mathrm{L}$. The relative quantitative measurement of target gene levels was performed using the $\Delta \Delta \mathrm{Ct}$ method [18]. As endogenous housekeeping control genes, T. cruzi Calmoduline and GAPDH genes were used. PCR assays were in triplicate and data were pooled.

\section{Statistical analysis}

All experiments were performed at least in biological triplicates and experimental duplicates. Data are expressed as arithmetic mean \pm Standard Deviation. Student's $t$ test or Mann-Whitney Rank-Sum test were adopted to analyze the statistical significance of the apparent differences. All statistical tests were performed with SigmaPlot for Windows Version 12 (Systat Software). Differences were considered statistically significant when $p<0.05$. 
Table 1 Identification and classification of $T$. cruzi strains/clones used in this work

\begin{tabular}{llll}
\hline Strain/Clone & DTU* & Origin & Host \\
\hline Dm28c & T. cruzi I & Carabobo, Venezuela & Didelphis marsupialis \\
$\mathbf{Y}$ & T. cruzi II & São Paulo, Brazil & Homo sapiens \\
$\mathbf{3 6 6 3}$ & T. cruzi III & Amazonas, Brazil & Panstrongylus geniculatus \\
$\mathbf{4 1 6 7}$ & T. cruzi IV & Amazonas, Brazil & Rhodnius brethesi \\
$\mathbf{L L 0 1 4}$ & T. cruzi V & Chaco, Argentina & Triatoma infestans \\
CL-14 & T. cruzi VI & Rio Grande do Sul, Brazil & Triatoma infestans \\
\hline
\end{tabular}

${ }^{*}$ DTU: Discrete Typing Unit.

\section{Ethical approval}

In order to perform the experimental infections with Trypanosoma cruzi, swiss mice obtained from the animal facilities of the Oswaldo Cruz Foundation (CECAL/Fiocruz, Rio de Janeiro, Brazil) were housed under specific pathogen free conditions in a 12-hour light-dark cycle with access to food and water ad libitum. Our protocols were approved by the Institutional Committee for Animal Ethics of Fiocruz (CEUA/Fiocruz, License LW-16/14).

\section{Results and discussion}

There are lines of evidence that NTPDases are related to virulence and infectivity in protozoan parasites [19-23]. However, most of the studies reported ecto-NTPDase enzymatic activities in intact parasites or plasma membrane fractions. Taking into account that plasma membranes share distinct ecto-nucleotidase activities, such as the $\mathrm{Mg}^{2+}$-dependent and $\mathrm{Mg}^{2+}$-independent ecto-ATPase activities [23], there is a lack of information regarding the specific contribution of each enzyme to these processes. It is possible that distinct ecto-enzymes could contribute to the parasite adaptation to stress conditions, as nutrients starvation or heat shock. Recently, Mariotini-Moura et al. [24] performed heterologous expression, purification and molecular characterization of TcNTPDase-1. By using specific polyclonal antibodies, they confirmed the presence of TcNTPDase-1 not only on the surface of $T$. cruzi, but also in the kinetoplast, nucleus, intracellular vesicles, flagellum and flagellum insertion region. The two latter localizations suggest that the enzyme may have a role in nutrient acquisition. It was also shown that the treatment of the parasite with anti-TcNTPDase-1 antibody decreases adhesion of $T$. cruzi to Vero cells, corroborating the importance of this enzyme to parasite-vertebrate host interaction.

Therefore, we used a gene expression quantification approach to evaluate the specific contribution of TcNTPDase1 to parasite virulence, infectivity and adaptation to heat shock. To evaluate gene expression of TcNTPDase-1 between distinct $T$. cruzi isolates, we selected representative strains or clones isolated from mammalian or invertebrate hosts, belonging from TcI to TcVI (Table 1). The TcNTPDase-1 mRNA levels were quantified in comparison to avirulent $\mathrm{Cl}-14 \mathrm{~T}$. cruzi clone (TcVI). The expression of TcNTPDase-1 was 7.2 1.5 times higher for the Dm28c clone (Tc I), than all other isolates, which showed similar low expression levels, like the avirulent Cl-14 clone (Figure 1A). To investigate if the increase in TcNTPDase-1 mRNA levels would result in higher ecto-nucleotidase activities, the ecto-ATPase and ectoADPase activities were estimated in intact epimastigotes (Figure 1B). Similar to mRNA levels, the ecto-ATPase
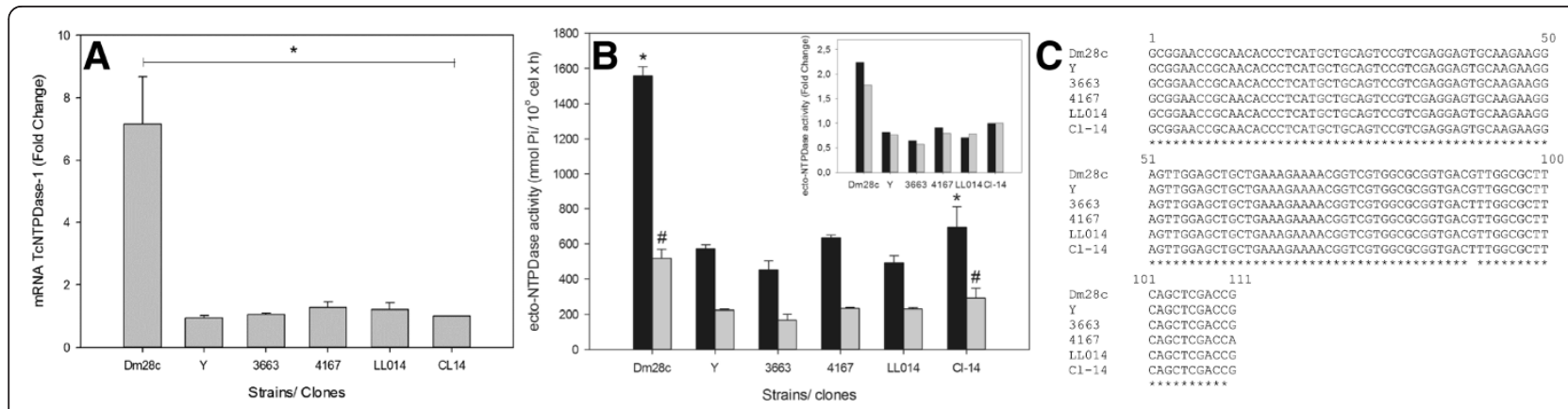

Figure 1 TcNTPDase-1 expression in epimastigote forms from distinct $T$. cruzi isolates. A. TcNTPDase-1 mRNA levels estimated by RT-qPCR. The relative quantification by $\Delta \Delta \mathrm{Ct}$ method was performed using the avirulent $\mathrm{Cl}-14$ clone as calibrator. B. Ecto-ATPase and ecto-ADPase activities between distinct $T$. cruzi strain/clones. The ecto-nucleotidase activities were estimated in T. cruzi epimastigotes, using 5 mM ATP or ADP as substrate. The inset shows the ecto-nucleotidase activities represented as Fold Change versus $\mathrm{Cl}-14$ clone. $\mathrm{C}$. Alignment of DNA sequence from PCR products for the TCNTPDase-1. The asterisks indicate identity between the nucleotides. * , \# $\mathrm{p}<0.05$ (versus Cl-14 clone, Mann-Whitney Rank-Sum test). 


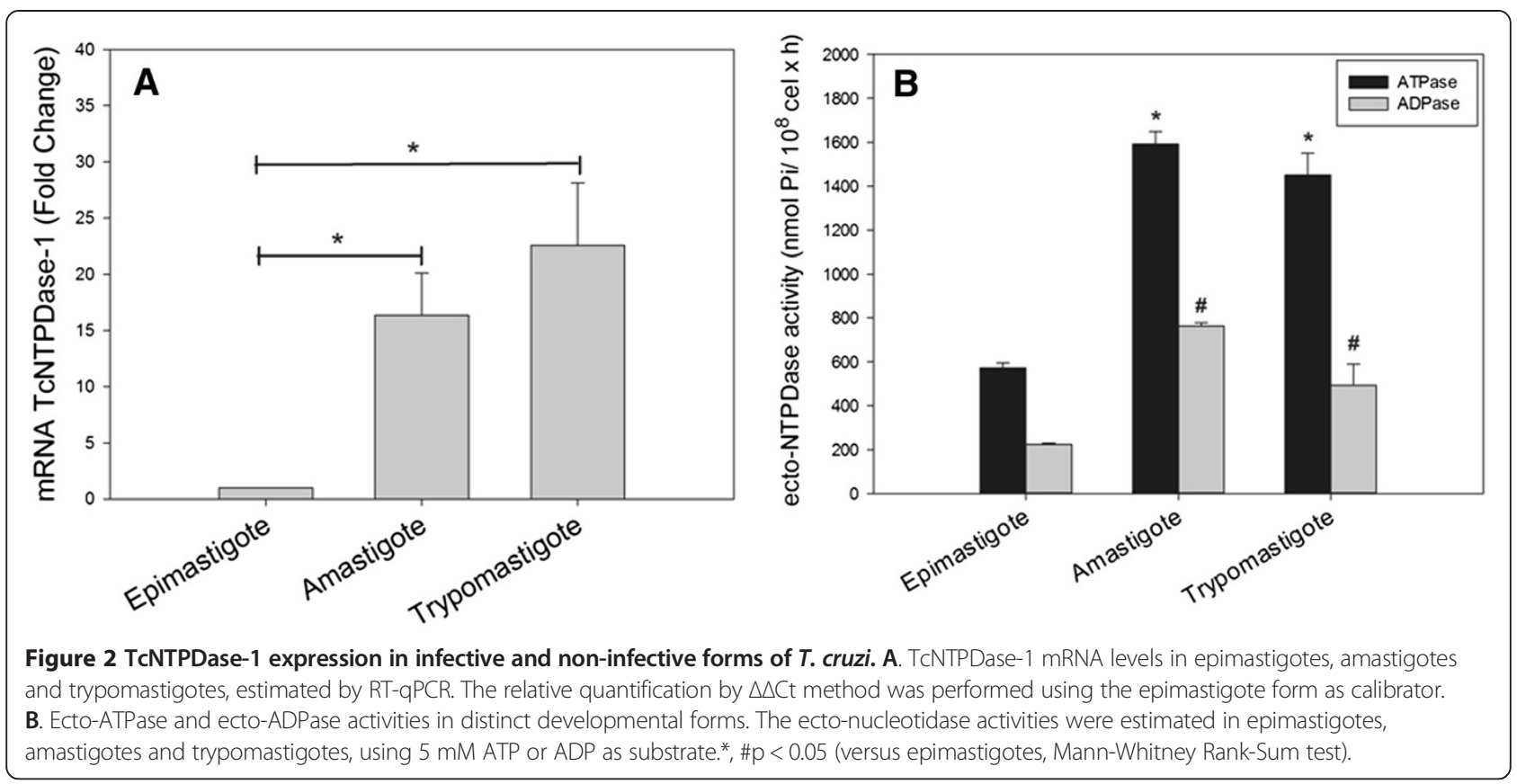

and ecto-ADPase activities were also higher for the Dm28c clone than the avirulent $\mathrm{Cl}-14$ clone. However, these increases (2.8 and 1.3 times higher to the ectoATPase and ecto-ADPase activities, respectively) were slightly lower than observed with the ecto-NTPDase-1 mRNA. Taking into account that, when using living epimastigotes, extracellular nucleotide hydrolysis might be correlated to different ecto-enzyme activities, and posttranslational regulation can also influence the level of active proteins, a significant increase in both mRNA and ecto-NTPDase activity levels suggests that the positive modulation of TcNTPDase- 1 expression in epimastigotes from Dm28c clone occurred both at gene and protein levels. To exclude the possibility that the existence of polymorphisms at the TcNTPDase- 1 gene could affect the gene expression analysis between these samples, PCR products for the TcNTPDase- 1 were sequenced. The DNA alignment indicated a high level of identity (98.2\%) between them (Figure 1C). Comparison between epimastigotes forms of the distinct strain/ clones suggested that the higher Dm28c TcNTPDase-1 expression could be associated to the parasite interaction with the invertebrate host, but other experiments should be performed for better evaluation. In fact,
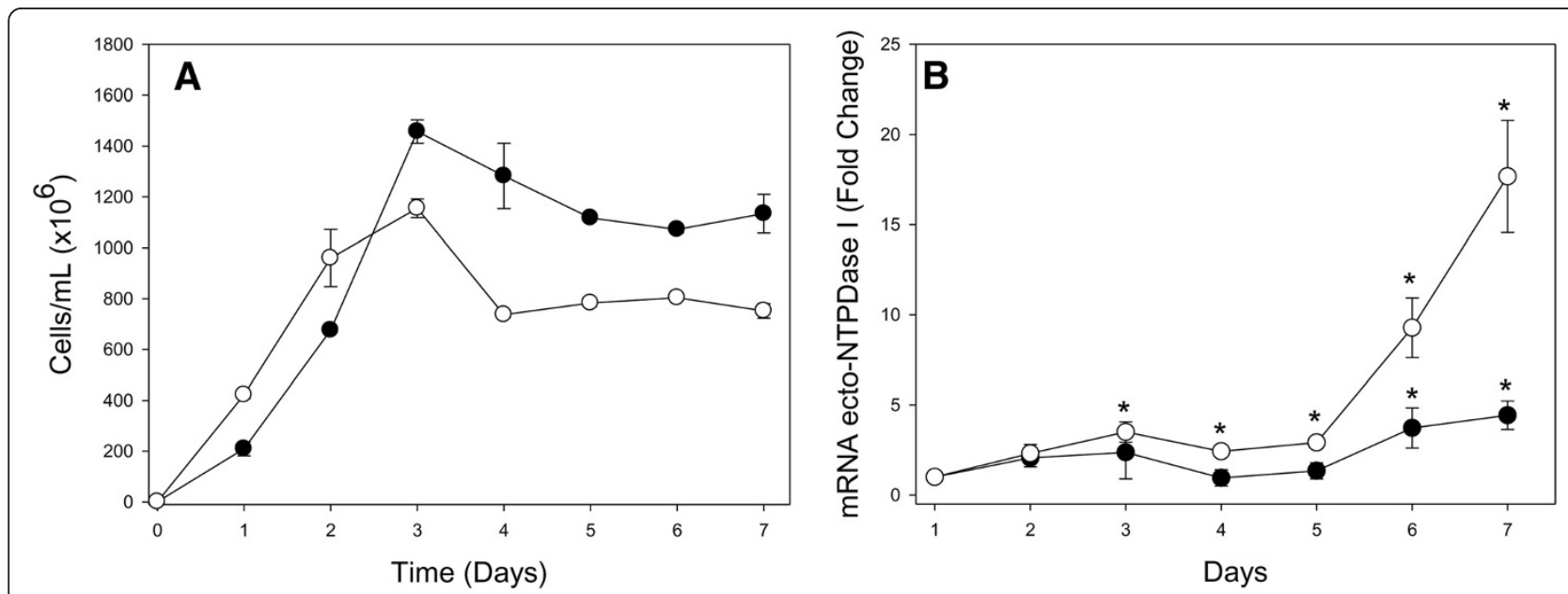

Figure 3 TcNTPDase-1 gene expression during epimastigote in vitro cultivation and induced by heat-shock. A. Growth curve of T. cruzi epimastigotes, in $\mathrm{BH}$ medium, at different temperatures. $(\bullet) 28^{\circ} \mathrm{C},(\bullet) 37^{\circ} \mathrm{C}$. B. TcNTPDase-1 mRNA levels during T. cruzi growth curve. The relative

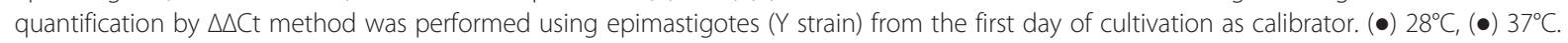
${ }^{*} p<0.05$ (versus day 1, Student's $t$ test). 
Dm28c is a $T$. cruzi clone with an elevated rate of colonization of the Rhodnius prolixus intestine, although it presents low virulence to the vertebrate host.

To investigate TcNTPDase-1 expression in infective parasite forms, we obtained cell-derived trypomastigotes and amastigotes, through the infection of Vero cells with bloodstream-derived trypomastigotes ( $\mathrm{Y}$ strain). TcNTPDase-1 mRNA levels (Figure 2A) and ecto-NTPDase activities (Figure 2B) were estimated and compared between developmental forms. A remarkable increase in the TcNTPDase-1 mRNA levels related to trypomastigote and amastigote forms was observed $(22.5 \pm 5.6$ and $16.3 \pm 3.8$ times higher than epimastigotes, respectively). The ecto-ATPase and ecto-ADPase activities were also significantly higher in trypomastigotes and amastigotes. The ectoATPase was 2.9 and 2.8 times higher and the ecto-ADPase was 3.0 and 3.4 times higher in tripomastigotes and amastigotes, respectively, when compared to the non-infective epimastigote form. Accordingly, we observed a simultaneous increase in mRNA and ecto-NTPDase activities in infectant forms of $T$. cruzi, suggesting the positive modulation of TcNTPDase-1 expression both at gene and protein levels. It corroborates with previous data obtained by Meyer-Fernandes et al. [23], which described increased $\mathrm{Mg}^{2+}$-dependent ecto-ATPase activities in trypomastigote and amastigote forms. The positive modulation of TcNTPDase-1 expression corroborates with the hypothesis that this enzyme plays an important role in T. cruzi infectivity.

During its life cycle, T. cruzi is exposed to different environments and temperatures between insect and mammalian hosts $\left(28\right.$ and $37^{\circ} \mathrm{C}$, respectively). Parasite exposition to $37^{\circ} \mathrm{C}$ induces an overexpression of various proteins, including heat shock proteins, which may be important to parasite invasion and proliferation $[25,26]$. Therefore, in order to evaluate the modulation of TcNTPDase-1 gene expression during cellular growth and in response to heat shock, in a strain that expresses low levels of Tc-NTPDase-1 in epimastigote forms, parasites from $Y$ strain were cultivated for 7 days at $28^{\circ} \mathrm{C}$ and $37^{\circ} \mathrm{C}$ (Figure $3 \mathrm{~A}$ ). At $28^{\circ} \mathrm{C}$, we observed a slight but significant increase at TcNTPDase- 1 mRNA level by the sixth and seventh days after the inoculum $(3.7 \pm 1.1$ and $4.4 \pm 0.8$ times higher than day 1 , respectively). In contrast, at $37^{\circ} \mathrm{C}$, the expression was $17.7 \pm 3.1$ times higher, at the seventh day after the inoculum, suggesting that heat shock and long-term cultivation could increase TcNTPDase-1 gene expression (Figure 3B). Similar data were observed for the protozoan parasite Trichomonas vaginalis by Frasson et al. [27]. These authors described the higher NTPDase expression levels in parasites cultivated in a limited serum supplementation condition, particularly for the clinical isolate. In conjunction, our results suggest the role of TcNTPDase-1 on T. cruzi infectivity and adjustment to stress conditions such as nutrients starvation and heat shock. Due to its importance for T. cruzi, further studies should be performed to investigate the role of TcNTPDase1 on the parasite virulence, in order to consider the possibility to evaluate this enzyme as a new candidate target for Chagas Disease chemotherapy.

\section{Additional file}

\section{Additional file 1: Figure S1. Standardization of Real-Time RT-qPCR for the T. cruzi ecto-NTPDase I gene expression analysis. A. Representative amplification curves for the TCNTPDase-1, GAPDH and Calmoduline targets. B. Representative melting curves for the TcNTPDase-1, GAPDH and Calmoduline targets. C. Validation of the $\triangle \triangle \mathrm{Ct}$ method for GAPDH and Calmoduline as housekeeping genes. Slopes: 0.1 (TCNTPDase-1 GAPDH) and -0.06 (TCNTPDase-1-Calmoduline).}

\section{Competing interests}

The authors declare that they have no competing interests.

\section{Authors' contributions}

Conceived the experiments: NLSG, VEV, JCF and OCM. Performed the experiments: NLSG, VEV, JCF, MBM. Analyzed the data: NLSG, VEV, JCF, MNS, RMB, OCM. RMB, MNS and OCM participated in study design and coordination and helped to draft the manuscript. All authors read and approved the final manuscript.

\section{Acknowledgements}

The authors thank Dr. Luciana P. Rangel for critical reading of the manuscript and English revision, as well as the Program for Technological Development in Tools for Health (PDTIS-Fiocruz) for the facilities on the Real Time PCR and DNA sequencing platforms and Coleção de Protozoários da Fundação Oswaldo Cruz (Colprot), for having provided the T. cruzi isolates used in this study. This work was supported in by a grant from FIOCRUZ and CNPq (PAPES VI - Process 407688/2012-9).

\section{Author details}

'Laboratorio de Biologia Molecular e Doenças Endêmicas, Instituto Oswaldo Cruz/ FIOCRUZ, Av. Brasil, 4365. Pavilhão Leônidas Deane, sala 209. Manguinhos, Rio de Janeiro, Brazil. 'Laboratório de Biologia Celular, Instituto Oswaldo Cruz/ FIOCRUZ, Rio de Janeiro, Brazil.

Received: 14 March 2014 Accepted: 27 September 2014

Published online: 05 October 2014

\section{References}

1. Rassi AJ, Rassi A, Rezende JM: American trypanosomiasis (Chagas disease). Infect Dis Clin N Am 2012, 26:275-291.

2. Steverding D: The history of Chagas disease. Parasit Vectors 2014, 7:317.

3. Zingales B, Andrade SG, Briones MRS, Campbell DA, Chiari E, Fernandes O, Guhl F, Lages-Silva E, Macedo AM, Machado CR, Miles MA, Romanha AJ, Sturm NR, Tibayrenc M, Schijman AG: A new consensus for Trypanosoma cruzi intraspecific nomenclature: second revision meeting recommends Tcl to TcVI. Mem Inst Oswaldo Cruz 2009, 104:1051-1054.

4. Campbell DA, Westenberger SJ, Sturm NR: The determinants of Chagas disease: connecting parasite and host genetics. Curr Mol Med 2004, 4:549-562.

5. Santana RA, Magalhães LK, Magalhães LK, Prestes SR, Maciel MG, da Silva GA, Monteiro WM, de Brito FR, de Aguiar Raposo Câmara Coelho LI, Barbosa-Ferreira JM, Guerra JA, Silveira H, Das Graças Vale Barbosa M: Trypanosoma cruzi strain Tcl is associated with chronic Chagas disease in the Brazilian Amazon. Parasit Vectors 2014, 7(1):267.

6. Bern C: Antitrypanosomal therapy for chronic chagas' disease. N Eng J Med 2011, 364(Bern, C):2527-2534.

7. Plesner L: Ecto-ATPases: identities and functions. Int Rev Cytol 1995, 158:141-214. 
8. Zimmermann H: Two novel families of ectonucleotidases: molecular structures, catalytic properties and a search for function. Trends Pharmacol Sci 1999, 20:231-236.

9. Langston HP, Ke Y, Gewirtz AT, Dombrowski KE, Kapp JA: Secretion of IL-2 and IFN-gamma, but not IL-4, by antigen-specific T cells requires extracellular ATP. J Immunol 2003, 170:2962-2970

10. Sansom FM, Robson SC, Hartland EL: Possible effects of microbial ecto-nucleoside triphosphate diphosphohydrolases on host-pathogen interactions. Microbiol Mol Biol Rev 2008, 72:765-781.

11. Fietto JLR, DeMarco R, Nascimento IP, Castro IM, Carvalho TMU, De Souza W, Bahia MT, Alves MJM, Verjovski-Almeida S: Characterization and immunolocalization of an NTP diphosphohydrolase of Trypanosoma cruzi. Biochem Biophys Res Comm 2004, 316:454-460.

12. Lima MT, Jansen AM, Rondinelli E, Gattass CR: Trypanosoma cruzi: properties of a clone isolated from CL strain. Parasitol Res 1991, 77:77-81.

13. Soares MB, Gonçalves R, Pyrrho AS, Costa DA, Paiva CN, Gattass CR: Balanced cytokine-producing pattern in mice immunized with an avirulent Trypanosoma cruzi. An Acad Bras Cienc 2003, 75(2):167-172.

14. Giarola NL, de Almeida-Amaral EE, Collopy-Júnior I, Fonseca-de-Souza AL, Majerowicz D, Paes LS, Gondim KC, Meyer-Fernandes JR: Trypanosoma cruzi: effects of heat shock on ecto-ATPase activity. Exp Parasitol 2013, 133(4):434-441.

15. Cohn CS, Gottlieb M: The acquisition of purines by trypanosomatids. Parasitol Today 1997, 13:231-235.

16. Santos RF, Pôssa MA, Bastos MS, Guedes PM, Almeida MR, Demarco R, Verjovski-Almeida S, Bahia MT, Fietto JL: Influence of ecto-nucleoside triphosphate diphosphohydrolase activity on Trypanosoma cruzi infectivity and virulence. PLoS Negl Trop Dis 2009, 3(3):e387.

17. De Souza MC, De Assis EA, Gomes RS, Marques da Silva EA, Melo MN, Fietto $J$, Afonso LC: The influence of ecto-nucleotidases on Leishmania amazonensis infection and immune response in C57B/6 mice. Acta Trop 2010, 115:262-269.

18. Livak KJ, Schmittgen TD: Analysis of relative gene expression data using real-time quantitative PCR and the 2(-Delta Delta $C(T))$ Method. Methods 2001, 25(4):402-408.

19. Nakaar V, Beckers CJ, Polotsky V, Joiner KA: Basis for substrate specificity of the Toxoplasma gondii nucleoside triphosphate hydrolase. Mol Biochem Parasitol 1998, 97:209-220.

20. De Jesus JB, De Sá Pinheiro AA, Lopes AH, Meyer- Fernandes JR: An ectonucleotide ATP-diphosphohydrolase activity in Trichomonas vaginalis stimulated by galactose and its possible role in virulence. Zeits der Naturforschung C 2002, 57:890-896.

21. Berrêdo-Pinho M, Peres-Sampaio CE, Chrispim PP, Belmont-Firpo R, Lemos AP, Martiny A, Vannier-Santos MA, Meyer-Fernandes JR: A Mg-dependent ecto-ATPase in Leishmania amazonensis and its possible role in adenosine acquisition and virulence. Arch Biochem Biophys 2001, 391:16-24.

22. Ennes-Vidal V, Castro RO, Britto C, Barrabin H, D'Avila-Levy CM, Moreira OC: CrATP interferes in the promastigote-macrophage interaction in Leishmania amazonensis infection. Parasitology 2011, 138(8):960-968.

23. Meyer-Fernandes JR, Saad-Nehme J, Peres-Sampaio CE, Belmont-Firpo R, Bisaggio DFR, Do Couto LC, De Souza ALF, Lopes AHSC, Souto-Padrón T: A Mg-dependent ecto-ATPase is increased in the infective stages of Trypanosoma cruzi. Parasitol Res 2004, 93:41-50.

24. Mariotini-Moura C, Bastos MS, de Castro FF, Trindade ML, de Souza Vasconcellos R, Neves-do-Valle MA, Moreira BP, de Freitas Santos R, de Oliveira CM, Cunha LC, Souto XM, Bressan GC, Silva-Júnior A, Baqui MM, Bahia MT, de Almeida MR, Meyer-Fernandes JR, Fietto JL: Trypanosoma cruz nucleoside triphosphate diphosphohydrolase 1 (TcNTPDase-1) biochemical characterization, immunolocalization and possible role in host cell adhesion. Acta Trop 2013, 130C:140-147.

25. Alcina A, Fresno M: Early and late heat-induced proteins during Leishmania 526 mexicana transformation. Biochem Biophys Res 1988, 156:1360-1367.
26. Rodrigues DC, Silva R, Rondinelli E, Ürményi TP: Trypanosoma cruzi: modulation of HSP70 mRNA stability by untranslated regions during heat shock. Exp Parasitol 2010, 126:245-253.

27. Frasson AP, Charão MF, Rosemberg DB, De Souza AP, Garcia SC, Bonorino C, Bogo MR, De Carli GA, Tasca T: Analysis of the NTPDase and ecto-5'-nucleotidase profiles in serum-limited Trichomonas vaginalis. Mem Inst Oswaldo Cruz 2012, 107(2):170-177.

doi:10.1186/s13071-014-0463-0

Cite this article as: Silva-Gomes et al:: Nucleoside triphosphate diphosphohydrolase 1 (TcNTPDase-1) gene expression is increased due to heat shock and in infective forms of Trypanosoma cruzi. Parasites \& vectors 2014 7:463.

\section{Submit your next manuscript to BioMed Central and take full advantage of:}

- Convenient online submission

- Thorough peer review

- No space constraints or color figure charges

- Immediate publication on acceptance

- Inclusion in PubMed, CAS, Scopus and Google Scholar

- Research which is freely available for redistribution
C Biomed Central 